DOI $10.31489 / 2020 \mathrm{M} 4 / 136-142$

UDC 512.54

\author{
V.I. Senashov ${ }^{1, *}$, I.A. Paraschuk ${ }^{2}$ \\ ${ }^{1}$ Siberian Federal University, Institute of Computational Modelling of SD RAS, Krasnoyarsk, Russia; \\ ${ }^{2}$ Siberian Federal University, Krasnoyarsk, Russia \\ (E-mail: sen1112home@mail.ru,ivan-ia-95@mail.ru)
}

\title{
On a bottom layer in a group
}

\begin{abstract}
We consider the problem of recognizing a group by its bottom layer. This problem is solved in the class of layer-finite groups. A group is layer-finite if it has a finite number of elements of every order. This concept was first introduced by S. N. Chernikov. It appeared in connection with the study of infinite locally finite $p$-groups in the case when the center of the group has a finite index. S. N. Chernikov described the structure of an arbitrary group in which there are only finite elements of each order and introduced the concept of layer-finite groups in 1948. Bottom layer of the group $G$ is a set of its elements of prime order. If have information about the bottom layer of a group we can receive results about its recognizability by bottom layer. The paper presents the examples of groups that are recognizable, almost recognizable and unrecognizable by its bottom layer under additional conditions.
\end{abstract}

Keywords: group, layer-finiteness, bottom layer, thin layer-finite group, spectrum, periodic group, Sylow subgroup, Abelian group, quasi-cyclic group, complete group.

\section{Introduction}

Every direct product of finite groups, having for each prime number $p$ only a finite number of factors with orders divisible by $p$, is a periodic group with a finite set of elements of each order. The direct product of quasi-cyclic $p$-groups containing only a finite number of factors of this type for each $p$ has the same property. Each direct product of a group of the first kind and a group of the second kind has the same property. However, the last products do not exhaust all periodic groups possessing a finite set of elements of each order. Groups with a finite set of elements of each order are called layer-finite, and a layer is called a set of elements of the same order.

This concept was first introduced by S. N. Chernikov. It appeared in connection with the study of infinite locally finite $p$-groups in the case when the center of the group has a finite index in it. S. N. Chernikov in 1948 described the structure of an arbitrary group in which there are an finite number of elements of each order, and in this work the term layer-finite groups appeared. The main result describing the structure of layer-finite groups was obtained by S. N. Chernikov also in 1948. It says that a group is then and only then layer-finite when it can be represented as the product of two elementwise permutation subgroups, of which the first is a layer-finite complete Abelian group, and the second is a layer-finite group with finite Sylow subgroups. The bottom layer of the group $G$ is the set of its elements of prime orders. In this work we will recognize the group by its bottom layer under additional conditions. It will be convenient for us to do this in the class of layer-finite groups.

For the convenience of reading the article, the last section contains well-known results that we referred to in the proof of the theorems as proposition with the corresponding number.

\section{Main part}

A group $G$ is called recognizable by the bottom layer under additional conditions if it is uniquely reconstructed by the bottom layer under these conditions. A group $G$ is said to be almost recognizable by

\footnotetext{
${ }^{*}$ Corresponding author.

E-mail: sen1112home@mail.ru
} 
its bottom layer under additional conditions if there are finitely many pairwise non-isomorphic groups with the same bottom layer the same as in the group $G$ under these conditions. A group $G$ is called unrecognizable by the bottom layer under additional conditions if there is an infinite number of pairwise non-isomorphic groups with the same bottom layer as in the group $G$ under these conditions.

Recall that the set of elements of prime order in a group is called its bottom layer.

Among the results on recognizability by the bottom layer, we can name those that describe the entire structure of the group by its bottom layer. For example: if the bottom layer of an infinite group consists of elements of order 2 and the group does not have non-identity elements of other orders, then $G$ is an infinite elementary Abelian 2-group. That is, the group under such conditions is recognizable by the bottom layer.

V. P. Shunkov proved that if the bottom layer in an infinite layer-finite group consists of one element of order 2, then the group is either quasi-cyclic or an infinite generalized group of quaternions [1]. In this example, groups are almost recognizable by the bottom layer.

The following series of groups gives an example of unrecognizability by the bottom layer: in groups $C_{p^{\infty}} \times C_{q}, C_{p^{\infty}} \times C_{q^{2}}, C_{p^{\infty}} \times C_{q^{3}}, \ldots$ the same bottom layer consisting of the $p-1$ element of order $p$ and the $q-1$ element of order $q$.

If the set of orders of elements of the bottom layer of an infinite group is small in terms of the number of its constituent numbers, but not in magnitude, then such examples of groups are quite rare. According to the figurative expression of Yu. I. Merzlyakov, they are comparable with "samples of lunar soil". Such examples include monsters of A. Yu. Olshansky [2]. Olshansky groups, as well as direct products of cyclic groups of prime order, are examples of groups without a single element coinciding with their bottom layer.

N. D. Gupta and V. D. Mazurov proved that for the group $G$, which, without a unit element, coincides with its bottom layer consisting of elements of orders 3,5 , one of the statements is true: 1) $G=F T$; where $F$ is a normal 5 -subgroup of nilpotent class at most two and $|T|=3$;2) $G$ contains a normal 3 -subgroups $T$ of nilpotent class at most three such that $G / T$ is a 5 -group [3]. In the same work, it was shown that a group that, without a unit element, coincides with its bottom layer consisting of elements of orders 2, 5, either contains an elementary Abelian 5-subgroup of index 2, or an elementary Abelian normal Sylow 2-subgroup [3].

Sometimes you can restore a group by the bottom layer of a group, sometimes you can say something about the properties of such a group. Among the results of the first type, we can name those that describe the entire structure of the group by its bottom layer, for example: if the bottom layer consists of elements of orders 2, 3, 5 and the group does not have non-identity elements of other orders, then A. S. Kondratiev and V. D. Mazurov proved that this is a group of even permutations on five elements [4]. The results of the second type include the establishment by V. D. Mazurov of the local finiteness of a group with a bottom layer consisting of elements of orders $2,3,5$, in which all other non-unit elements are of order 4 [5].

In the theory of finite groups, a similar concept of spectrum recognition of a group is considered.

The spectrum of a finite group is the set of orders of its elements. The spectrum of a group $G$ is denoted by $\omega(G)$. A finite group $G$ is called spectrum recognizable if any finite group whose spectrum coincides with the spectrum of the group $G$ is isomorphic to $G$. A group $G$ is said to be almost recognizable by spectrum if there exist finitely many pairwise nonisomorphic groups with the same spectrum as the group $G$. A group $G$ is said to be unrecognizable by spectrum if there is an infinite number of pairwise nonisomorphic groups with the same spectrum as the group $G$.

It was proved in [6] that the symmetric groups $S_{n}$ are recognizable by spectrum for $n \notin\{2,3,4,5,6,8$, $10,15,16,18,21,27,33,35,39,45\}$.

In 1994, W. Shi and R. Brandl proved spectrum recognizability of an infinite series of simple linear groups $L_{2}(q), q \neq 9[7,8]$. 
Let $G$ be a finite group and $\omega(G)=\omega\left(S_{6}(2)\right)$. Then $G$ is isomorphic to $S_{6}(2)$ or $O_{+}^{8}$. In particular, the group $S_{6}(2)$ is almost recognizable by spectrum [9].

An example of a group not recognized by the spectrum is the group $A_{6}$ with the spectrum $1,2,3,5,4,8,9$ (there are infinitely many groups, one of which is the group $A_{6}$ ) [10]. Also, the group $L_{3}(3)$ with the spectrum, $1,2,3,4,8,9,13,16,27$, is unrecognizable by the spectrum [10].

By the theorem of A. V. Vasiliev (Proposition 1), a finite simple non-Abelian group $U_{4}(5)$ is not recognizable by spectrum. In this regard, we prove the result of recognizability of this group simultaneously by the spectrum and by the bottom layer.

Theorem 1. Let $G$ be a finite simple group $U_{4}(5)$ and $H$ be a finite group with the property $\omega(H)=\omega(G)$ and the bottom layer same as the group $U_{4}(5)$. Then $H \cong G$. That is, the group $U_{4}(5)$ is an unique finite group with such a spectrum and a bottom layer.

Proof. Indeed, let $G$ be a finite simple group $U_{4}(5)$ and $H$ be a finite group with the property $\omega(H)=\omega(G)$.

By the theorem of A. V. Vasiliev (Proposition 1), in addition to the group $U_{4}(5)$, there is only one such group $H \cong G(\gamma)$, where $\gamma$ is a field automorphism of the group $G$ of order 2 . The groups $U_{4}(5)$ and $H$ have the same spectrum, while these groups have different bottom layers, which differ at least by an element of order 2 . Thus, the group $U_{4}(5)$ is an unique finite group with such a spectrum and a bottom layer. The theorem is proved.

Definition. Recall that if the orders of all elements of a group are finite, then the group is called periodic.

Theorem 2. If $G$ is a complete group in which $Z(G)$ is layer-finite and $G / Z(G)$ is a periodic group containing for each prime $p$ only a finite number of $p$-elements, then the group $G$ is recognizable by the bottom layer among groups with such properties.

Proof. Indeed, let the group $G$ satisfy the indicated conditions. Since $Z(G)$ is layer-finite and $G / Z(G)$ is a periodic group containing for each prime $p$ only a finite number of $p$-elements, by proposition 2, the group $G$ is layer-finite. Since, by Proposition 3, each complete subgroup of a layer-finite group $G$ is contained in the center of the group $G$, then since $G$ is complete, then it is Abelian.

By Proposition 4, the complete Abelian group $G$ decomposes into a direct sum of subgroups isomorphic to the additive group of rational numbers or to quasicyclic groups, possibly for different prime numbers. There can be no rational groups in this extension, since $G$ is a layer-finite group and, therefore, there are no elements of infinite order in it. Since the direct product of quasi-cyclic groups is obviously restored from the bottom layer, the group $G$ is recognizable by the bottom layer among groups with the properties as in the theorem. The theorem is proved.

Definition. Layer-finite group is called a thin layer-finite group if all of its Sylow subgroups are finite.

Theorem 3. Let $G$ be a group in which the center contains a complete layer-finite subgroup $R$ such that the factor group $G / R$ is a thin layer-finite group. Then the group $G$ is recognizable by the bottom layer among groups with such properties.

Proof. Suppose that the group $G$ satisfies the indicated conditions. Since $G$ is a group in which the center contains such a complete layer-finite subgroup $R$ such that the factor group $G / R$ is a thin layer-finite group, by Proposition 5 the group $G$ is layer-finite .

Since by Proposition 3 each complete subgroup of a layer-finite group $G$ is contained in the center of the group $G$, the group $G$, being complete, is Abelian. Then, by Proposition 4, the group $G$ decomposes into a direct sum of subgroups isomorphic to the additive group of rational numbers or to quasi-cyclic groups, possibly for different prime numbers.

Among the direct components there can only be quasi-cyclic groups, since the group of rational numbers has elements of infinite order, and $G$ is a layer-finite group and therefore cannot contain elements of infinite order. So $G$ decomposes into a direct sum of quasi-cyclic primary groups, and such 
a group is recognizable by the bottom layer among groups with the properties as in the theorem. The theorem is proved.

Theorem 4. Let $G$ be a complete nilpotent $p$-group with finite bottom layer. Then the group $G$ is recognizable by the bottom layer among groups with such properties.

Proof. Indeed, since $G$ is a complete nilpotent $p$-group with a finite bottom layer, by Proposition 6 the group $G$ is layer-finite. Given that $G$ is a complete group and repeating the final part of the previous proof, we see that the group $G$ is recognizable by the bottom layer among groups with the properties as in the theorem. The theorem is proved.

Theorem 5. Let $G$ be a complete periodic group in which for each prime $p$ there is only a finite number of Sylow $p$-subgroups and for every prime $p$ there is at least, one Sylow $p$-subgroup in $G$, which is a layer-finite group. Then the group is recognizable by the bottom layer among groups with such properties.

Proof. Suppose that the group $G$ satisfies the given conditions. Because $G$ is the group in which the conditions are satisfied: $G$ is the periodic group; for each prime number $p$ there is only a finite number of Sylow $p$-subgroups; for every prime number $p$ there is at least one Sylow $p$-subgroup in $G$, which is a layer-finite group, then by Proposition 7 the group $G$ is layer-finite. Based on the fact that the group is layer-finite, complete, and applying Propositions 3 and 4 , we have that the group $G$ is complete Abelian and decomposes into a direct sum of subgroups isomorphic to the additive rational group or quasi-cyclic groups, may be according to different prime numbers.

Among the direct components there can be only quasi-cyclic groups, since the group of rational numbers has elements of infinite order, and $G$ is a layer-finite group and therefore cannot contain elements of infinite order. Therefore, $G$ decomposes into a direct sum of quasi-cyclic primary groups, and such a group is recognizable by the bottom layer among groups with the properties as in the theorem. The theorem is proved.

In proving the results of the paper, we used the following theorems, which were referred to as proposition with the corresponding number.

Proposition 1 (A.V. Vasiliev [10]). Let $G$ be a finite simple group $U_{4}(5)$ and $H$ be a finite group with the property $\omega(H)=\omega(G)$. Then $H \cong G$ or $H \cong G(\gamma)$, where $\gamma$ is a field automorphism of the group $G$ of order 2. In particular, $h(G)=2$.

By $h(G)$ we denote the number of non-isomorphic groups with the same spectrum.

Proposition 2 (R. Baer [11]). The following properties are equivalent;

a) $G$ is a layer-finite group;

b) $Z(G)$ is layer-finite and $G / Z(G)$ is a periodic group containing for each prime $p$ only a finite number of $p$-elements;

c) there is a subgroup $S$ in the center of $G$ such that $S$ and $G / S$ are layer-finite groups.

Proposition 3 (S.N. Chernikov, Lemma 3.1. from [12]). Each complete subgroup of a locally normal (in particular, layer-finite) group is contained in the center of the group.

Proposition 4 (Theorem 9.1.6 from [13]). A nonzero complete Abelian group can be decomposed into a direct sum of subgroups isomorphic to the additive rational group or quasi-cyclic groups, may be for different prime numbers.

Proposition 5 (S. N. Chernikov, Theorem 1 from [14]). A group $G$ if and only if is layer-finite if its center contains such a complete layer-finite subgroup $R$ such that the factor group $G / R$ is a thin layer-finite group.

Proposition 6 (S. N. Chernikov [15]). If a nilpotent p-group of $G$ contains only a finite set of elements of some non-unit order, then it is layer-finite.

Proposition \%. (R. Baer [11]). A group $G$ is layer-finite if and only if the following conditions are satisfied:

a) $G$ is a periodic group;

b) for each prime number $p$ there is only a finite number of Sylow $p$-subgroups; 
c) for every prime number $p$ there is at least one Sylow $p$-subgroup in $G$, which is a layer-finite group.

\title{
References
}

1 Шунков В.П. Об одном классе $p$-групп / В.П. Шунков // Алгебра и логика. - 1970. - 4(9). - C. 484-496.

2 Ольшанский А.Ю. Бесконечная группа с подгруппами простых порядков / А.Ю. Ольшанский // Изв. АН СССР. Сер. матем. - 1980. - 2(44). - С. 309-321.

3 Gupta N.D. On groups with small orders of elements / N.D. Gupta, V.D Mazurov // Bull. Austral. Math. Soc. - 1999. - 60. - 197-205.

4 Кондратьев А.С. Распознавание знакопеременных групп простой степени по порядкам их элементов / А.С. Кондратьев, В.Д. Мазуров // Сиб. матем. журн. - 2000. - 2(41). - С. 360371.

5 Мазуров В.Д. О группах экспоненты 60 с точными порядками элементов / В.Д. Мазуров // Алгебра и логика. - 2000. - 3(39). - С. 189-198.

6 Горшков И.Б. Распознаваемость симметрических групп по спектру / И.Б. Горшков // Алгебра и логика. - 2014. - 6(53). - С. 693-703.

7 Shi W. A characteristic property of $J_{1}$ and $P S L_{2}\left(2^{n}\right) /$ W. Shi // Adv. Math. - 1987. - 16. 397-401.

8 Brandl R. The characterization of $\operatorname{PSL}(2, q)$ by its element orders / R. Brandl, W. Shi // J. Algebra. - 1994. - 1(163). - 109-114.

9 Мазуров В.Д. Характеризация конечных групп множествами порядков их элементов / В.Д. Мазуров // Алгебра и логика. - 1997. - 1(6). - С. 37-53.

10 Васильев А.В. О распознавании всех конечных неабелевых простых групп, простые делители порядков которых не превосходят 13 / А.В. Васильев // Сиб. матем. журн. - 2005. 2(46). - C. $315-324$.

11 Baer R. Finiteness properties of groups / R. Baer // Duke Math. J. - 1948. - 4(15). - 1021-1032.

12 Черников С.Н. О слойно конечных группах / С.Н. Черников // Мат. сб. - 1958. - 3(45). C. 415,416 .

13 Каргаполов М.И. Основы теории групп. - 3-е изд. / М.И. Каргаполов, Ю. И. Мерзляков. - М.: Наука, 1982. - 288 с.

14 Черников С.Н. Бесконечные слойно конечные группы / С.Н. Черников // Мат. сб. - 1948. $-1(22)$. - C. 101-133.

15 Черников С.Н. О специальных $p$-группах / С.Н. Черников // Мат. сб. - 1950. - 2(27). C. $185-200$.

В.И. Сенашов, И.А. Паращук

\section{Группадағы төменгі қабат туралы}

\begin{abstract}
Мақалада группадағы төменгі қабат бойынша танылу мәселесі қарастырылды. Бұл мәселе қабатты шекті группалардың класында шешіледі. Группа қабатты шекті деп аталады, егер группаның әрбір ретінде шекті санды элемент бар болса. Бұл ұғымды С.Н. Черников енгізген. Ол шексіз локальдышекті $p$-группаларын группаның центрінде шекті индекс болған жағдайда зерттеуге байланысты пайда болды. С.Н. Черников 1948 жылы әрбір реттегі элементтер жиыны шексіз кез келген группаның құрылымын сипаттады және осы жұмыста қабатты шекті группалар термині пайда болды.
\end{abstract}


$G$ группасының төменгі қабаты деп оның жай ретті элементтер жиынын айтамыз. Төменгі қабат туралы мәліметтер бойынша группаның төменгі қабаты бойынша танылуы туралы нәтижелерді аламыз. Жұмыста төменгі қабаты бойынша танылатын, танылатын дерлік, танылмайтын группалардың мысалдары келтірілген.

Kiлm сөздер: группа, қабатты шектілік, төменгі қабат, жұқа қабатты шекті группа, спектр, периодты группа, силов ішкі группасы, абельдік группа, квазициклдік группа, толық группа.

\section{В.И. Сенашов, И.А. Паращук}

\section{О нижнем слое в группе}

В статье рассмотрен вопрос о распознавании группы по её нижнему слою. Этот вопрос решается в классе слойно конечных групп. Группа называется слойно конечной, если она имеет конечное число элементов каждого порядка. Это понятие впервые было введено С.Н. Черниковым. Оно появилось в связи с изучением бесконечных локально конечных $p$-групп в случае, когда центр группы имеет конечный индекс в ней. В 1948 г. С.Н. Черников описал строение произвольной группы, в которой бесконечно множество элементов каждого порядка, и ввел понятие слойно конечных групп. Нижним слоем группы $G$ называется множество её элементов простых порядков. По информации о нижнем слое авторами статьи получены результаты о распознаваемости группы по нижнему слою. Приведены примеры групп, распознаваемых по нижнему слою, почти рапознаваемых и нераспознаваемых групп при дополнительных ограничениях.

Ключевые слова: группа, слойная конечность, нижний слой, тонкая слойно конечная группа, спектр, периодическая группа, силовская подгруппа, абелева группа, квазициклическая группа, полная группа.

\section{References}

1 Shunkov, V.P. (1970). Ob odnom klasse $p$-hrupp [On a one class of p-groups]. Alhebra $i$ lohikaAlgebra and logic, No. 4(9), 484-496 [in Russian].

2 Ol'shanckiy, A.Yu. (1980). Beskonechnaia hruppa s podhruppami prostykh poriadkov [Infinite group with subgroups of prime orders]. Izvestiia AN SSSR, Seriia matematika - Izv. of USSR Academy of Sciences, Ser. math., No. 2(44), 309-321 [in Russian].

3 Gupta, N.D. \& Mazurov, V.D. (1999). On groups with small orders of elements. Bull. Austral. Math. Soc., 60. 197-205.

4 Kondratiev, A.S. \& Mazurov, V.D.(2000). Raspoznavanie znakoperemennykh hrupp prostoi stepeni po poriadkam ikh elementov [Recognition of alternating groups of a prime degree by the orders of their elements]. Sibirskii matematicheskii zhurnal - Siberian math. journal, No. 2(41), 360-371 [in Russian].

5 Mazurov, V.D. (2000). O hruppakh eksponenty $60 \mathrm{~s}$ tochnymi poriadkami elementov [On groups of exponent 60 with exact element orders]. Alhebra i lohika - Algebra and logic, No. 3(39), 189-198 [in Russian].

6 Gorshkov, I.B. (2014). Raspoznavaemost simmetricheskikh hrupp po spektru [Recognition of symmetric groups by spectrum]. Alhebra i lohika - Algebra and logic, No. 6(53), 693-703 [in Russian].

7 Shi, W. (1987). A characteristic property of $J_{1}$ and $P S L_{2}\left(2^{n}\right)$. Adv. Math., 16. 397-401.

8 Brandl, R., \& W. Shi (1994). The characterization of $\operatorname{PSL}(2, q)$ by its element orders. J. Algebra, No. 1(163), 109-114. 
9 Mazurov V.D. (1997). Kharakterizatsiia konechnykh hrupp mnozhestvami poriadkov ikh elementov [Characterization of finite groups by the sets of orders of their elements]. Alhebra i lohika Algebra and logic, No. 1(36), 37-53 [in Russian].

10 Vasilev, A.V. (2005). O raspoznavanii vsekh konechnykh neabelevykh prostykh hrupp, prostye deliteli poriadkov kotorykh ne prevoskhodiat 13 [On the recognition of all finite non-Abelian simple groups, prime divisors of the orders of which do not exceed 13]. Sibiarskii matematicheski zhurnal - Siberian math. journal, No. 2(46), 315-324 [in Russian].

11 Baer, R. (1948). Finiteness properties of groups Duke Math. J., No. 4(15), 1021-1032.

12 Chernikov, S.N. (1958). O sloino konechnykh hruppakh [On layer-finite groups]. Matematicheskii sbornik - Math. Collection, No. 3(45), 415-416 [in Russian].

13 Kargapolov, M.I., \& Merzliakov, Yu.I. (1982). Osnovy teorii hrupp [Fundamentals of Group Theory]. (3d Ed.). Moscow: Nauka [in Russian].

14 Chernikov, S.N. (1948). Beskonechnye sloino konechnye hruppy [Infinite layer-finite groups]. Matematicheskii sbornil - Math. Collection, No. 1(22), 101-133 [in Russian].

15 Chernikov, S.N. (1950). O spetsialnykh $p$-hruppakh [On special p-groups]. Matematicheskii sbornik - Math. Collection, No. 2(27), 185-200 [in Russian]. 